https://doi.org/10.18485/iipe_conv_conf.2021.ch1

\title{
THE “BLUE HOMELAND” AND ERDOĞAN'S RHETORIC: STATE DOCTRINE OR POPULIST NARRATIVE?
}

\author{
Anthony Deriziotis ${ }^{1}$
}

\begin{abstract}
Rtd Adm Cem Gürdeniz's "Blue Homeland" dogma was first presented in June 2006, and later it was refined into state doctrine by former RAdm Cihat Yaycl. It was aiming to increase Turkey's control of the three seas surrounding it, to consolidate its regional and international influence, and to get access to energy sources that would support its economic growth without dependence on other countries. The doctrine represents a nationalist, irredentist approach to Turkey's maritime position that lies within the neo-Ottomanist narrative that has emerged since the Justice and Development Party has been in power. The Blue Homeland doctrine is in complete contrast with the "zero problems with neighbours" approach, theorised by former P.M. A. Davutoğlu and adopted by AKP leader R.T. Erdoğan. Domestic and regional developments have led the Turkish President to reposition Ankara's foreign policy following the Arab Spring developments and the AKP's switch to close partnerships with the far-right Nationalist Movement Party.

The aim of this paper is to question how much of this doctrine that has been driving conflictual bilateral relations with Greece, has indeed been incorporated into Ankara's foreign policy.

Keywords: Turkey, Blue Homeland, Greece, tension, Aegean Sea, East Mediterranean Sea, irredentism, AKP, foreign policy.
\end{abstract}

\section{INTRODUCTION}

On June 14, 2006, Adm. Cem Gürdeniz presented a new, rather radical approach to Turkey's sea borders on all three seas surrounding it, namely the

\footnotetext{
${ }^{1}$ Faculty of Turkish and Modern Asian studies, N.K. University of Athens. aderiziot@turkmas.uoa.gr
} 
Meditarranean Sea, the Aegean Sea, and the Black Sea, calling it "Mavi Vatan". 2 A few years later, this was refined into state doctrine by former RAdm Cihat Yaycl and was strongly supported by a number of other navy officers ${ }^{3}$. Eventually, this doctrine became the basis for a comprehensive foreign policy.

The "Blue Homeland" was aiming to achieve Turkish control of the three seas surrounding it, to consolidate its regional and international influence, and to get access to energy sources that would support its economic growth without dependence on other countries. Beyond the doctrine's declared goals, there are further implications. The doctrine represents a nationalist, irredentist approach to Turkey's maritime position that lies within the neoOttomanist narrative that has emerged since the Justice and Development Party has been in power.

The aim of this paper is to question how much of this doctrine that has been driving conflictual bilateral relations with Greece has indeed been incorporated into Ankara's foreign policy.

\footnotetext{
${ }^{2}$ Mavi Vatan means "Blue Homeland", and from this point onwards in this paper, it will be referred to as such.

${ }^{3}$ Admirals Soner Polat, Özden Özer, Mustafa Özbey and Cem Aziz Çakmak have defended the doctrine publicly. See S. Polat, Mavi Vatan için jeopolitik rota: Doğu Akdeniz, Kıbrıs ve Ege'deki kavgayı anlatan tespitler ve öneriler [A geopolitical course to Blue Homeland: findings and proposals on the conflict in the Eastern Mediterranean, Cyprus and the Aegean], Istanbul: Kaynak, 2019; C. Gürdeniz, “Amiral Cem Aziz Çakmak'ı 'Mavi Vatan'ın sonsuzluğuna uğurlarken" [Our farewell to Adm Cem Aziz Çakmak who has departed to the eternal Blue Homeland], Aydınlık, July 4, 2015; Ö. Örnek, Milgem'in öyküsü [The Milgem history program], Istanbul: Kırmızı Kedi, 2016 and "Tümamiral Mustafa Özbey'den çağrı: Mavi Vatan okul müfredatına girsin" [An appeal by RAdm Mustafa Özbey: that Blue Homeland is included in school programs], Aydınlık, April 21, 2020.
} 


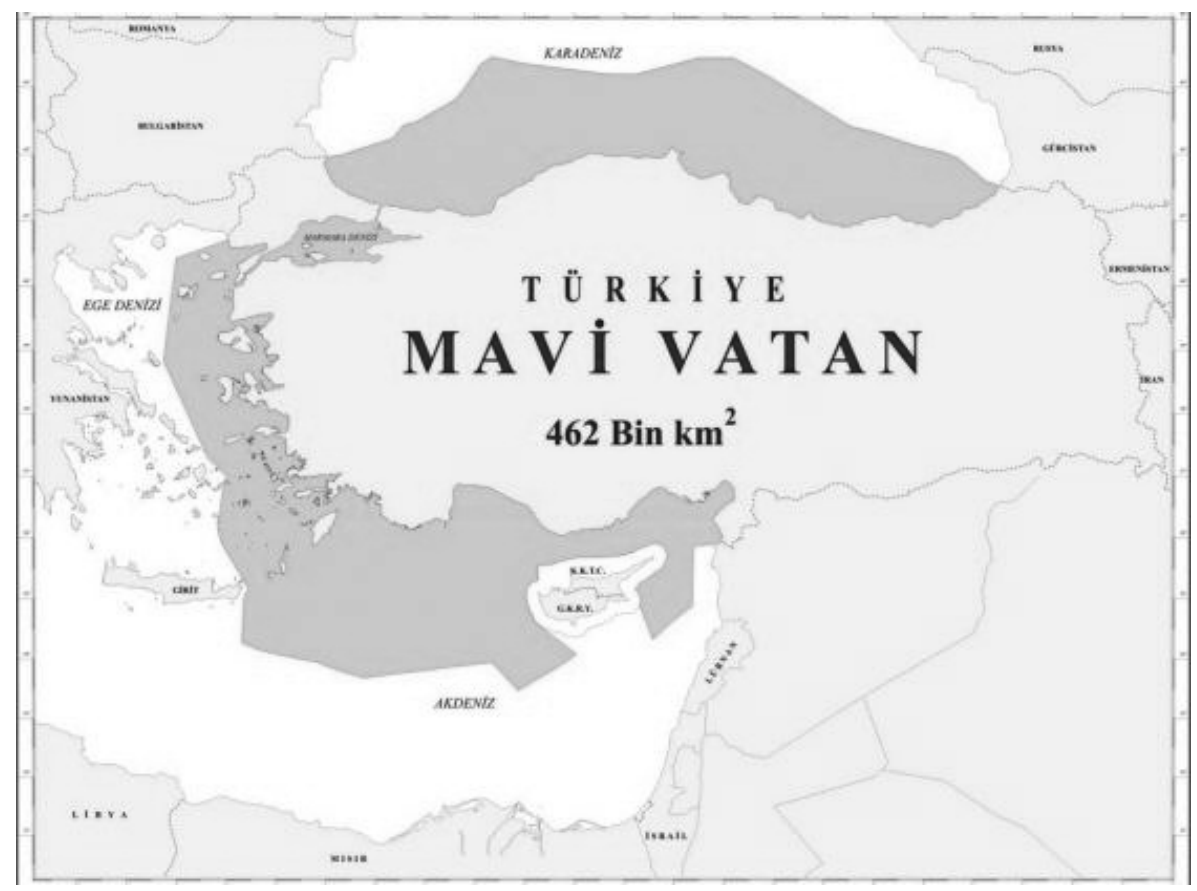

THE “BLUE HOMELAND”: FROM THEORY TO DOCTRINE

In the early years of the 2000s, Prime Minister and AKP leader, R.T. Erdoğan, implemented A. Davutoğlu's, at the time his foreign policy advisor ${ }^{4}$, "zero problems with neighbours" policy. This marginalised the previous "forward defence" policy - a security-oriented foreign policy introduced in the early post-Cold War years - and essentially side-lined the emerging "Blue Homeland" doctrine. Davutoğlu's foreign policy approach was aimed at substantially boosting Turkey's influence in former Ottoman Empire lands through soft power, in contrast to the 1990s increased use of military force in foreign policy.

Following the Arab Spring and the swift demise of Davutoğlu's doctrine, as well as his ousting from the AKP in 2016, Turkey adopted a new version of

\footnotetext{
${ }^{4}$ Ahmet Davutoğlu served as Foreign Minister (2009-14) and Prime Minister (2014-16) of Turkey.
} 
the 1990s "forward defence" doctrine, once again focusing on a securityoriented foreign policy, the re-securitization of the Kurdish issue, and relations with neighbouring countries. ${ }^{5}$ Apart from regional developments, changes on the domestic front have also influenced Ankara's repositioning of its foreign policy. It appears that the political actors with whom the AKP collaborated after 2015 to rule the country, in the form of the AKP's close partnership with the far-right Nationalist Movement Party, have consolidated kemalist and nationalist influence, as well as the involvement of the Turkish Armed Forces in foreign policy implementation. ${ }^{6}$

Clearly, a security-oriented foreign policy is not a new idea in Turkish history. However, a maritime doctrine of the calibre of the 'Blue Homeland', despite its flaws and its lack of coherent analysis, was something new. Ankara's maritime policy for more than 30 years has been limited mainly to bilateral disputes with Greece over territorial waters, the continental shelf, the Cyprus issue and the search-and-rescue jurisdiction over the Aegean Sea. The developments in the East Mediterranean Sea in the early 2000s, with the natural gas discoveries in Israel (1999 and 2000) and Egypt (2003), followed by Cyprus' EEZ delineation agreements with neighbouring states ${ }^{7}$, augmented Ankara's long-lasting geopolitical concerns and, together with its energy deficit ${ }^{8}$, aggravated a multi-layered maritime dispute between Greece, Turkey, and Cyprus. This dispute was also directly related to the 2004 Cyprus EU accession and, later that year, to the rejection of the Annan Plan by the GreekCypriots and the unsurprising freezing of Turkey's EU accession. The latter

\footnotetext{
${ }^{5}$ The dominant idea here is that Turkey needs powerful armed forces to employ hard power in order to protect its interests and security. This was clearly implemented in Syria and Libya. See, Nebahat Tanrıverdi Yaşar, "Syria and Libya's contributions to the evolution of the Turkish "Forward Defence" doctrine", Syria Transition Challenges Project: Research Project Report 7, Geneva Centre for Security Policy: 2021, pp. 6-10.

${ }^{6}$ These political actors are, apart from the Islamists, the MHP, the Eurasianists, and the Vatan Party.

${ }^{7} 2003$ with Egypt, 2007 with Lebanon, 2010 with Israel. See, Ayla Gürel, Fiona Mullen, Harry Tzimitras, "The Cyprus Hydrocarbons Issue: Context, Positions and Future Scenarios", PCC Report 1, Peace Research Institute Oslo, 2013, pp. 3, 14-15.

${ }^{8}$ At the time, energy was the main cause of the country's budget deficit. Galip Dalay, "Turkey, Europe, and the Eastern Mediterranean: Charting a Way Out of the Current Deadlock", Brookings Doha Center Policy Briefing - January 2021, pp. 3-4.
} 
would have been possible only with a positive result in the Annan Plan referendum. Another twist was added with the Libya controversy, further complicating the dispute with a new geopolitical dimension. ${ }^{9}$

The "Blue Homeland" has essentially evolved as the maritime segment of Ankara's "forward defence" policy and has added to the friction in Turkey's bilateral relations with its maritime neighbours. In March 2006, geographers Juan Luis Suárez de Vivero and Juan Carlos Rodríguez Mateos, from the University of Seville in Spain, published their article "Maritime Europe and EU Enlargement: A Geopolitical Perspective ${ }^{10}$, which included a map of the EU-member states' Exclusive Economic Zones, thus validating Cyprus's territorial claims ${ }^{11}$ that have been strenuously disputed by Ankara. ${ }^{12}$ This "map of Seville" was an EU-funded project ${ }^{13}$ that has been used by the EU in numerous official documents and has received strong criticism from Turkey for serving the EU's- especially Greece and Cyprus'- interests, while it ignored Turkey's claims in the Aegean and the East Mediterranean Seas. ${ }^{14}$ Certain ultra-conservative parts of Turkey's political scene went on to express their

\footnotetext{
${ }^{9}$ Galip Dalay, pp.5-6.

${ }^{10}$ The article was received by Elsevier on 8 October 2004 and was accepted on 29 November of the same year.
}

${ }^{11}$ J. R. Mateos and J. L. Suárez De Vivero, "Maritime Europe and EU Enlargement: A Geopolitical Perspective", Marine Policy, Vol. 30, No. 2, March 2006, pp. 167-172. See also, Aurélien Denizeau, "Mavi Vatan, the "Blue Homeland": The Origins, Influences and Limits of an Ambitious Doctrine for Turkey", Ifri, April 2021, pp. 6-7.

${ }^{12}$ Cyprus, at that time, had been in the process of delineating its EEZ, drawing on the principles of the 1982 UNCLOS and having already signed a maritime border agreement with Egypt in 2003.

${ }^{13}$ The EU, prior to the 2004 enlargement, wanted to invest in maritime spatial planning, therefore, it needed a clear view of its member states' EEZs in order to invest in wind power, fish farming, tourism, ports, and shipyards. See, Cem Gürdeniz, "The Map of Seville and the plot to cut Turkey off from the Aegean and Mediterranean seas", United World, https://uwidata.com/13877-the-map-of-seville-and-the-plot-to-cut-turkey-off-from-theaegean-and-mediterranean-seas/

${ }^{14}$ The criticism focused on two issues. First, the map was based on the 1982 UN Convention on the Law of the Sea (UNCLOS) principle that every island has territorial waters and that if it also has a social life, this gives it a continental shelf and an exclusive economic zone (EEZ), but it did not engage the doctrine of fairness that is also included in the same Convention. Second, criticism stresses the fact that Turkey is not a member of the 1985 UNCLOS. 
disbelief in the EU, considering the creation of the map and its use as a plot against Turkey, created in a way to serve maximalist claims by Greece and Cyprus, which Turkey would eventually be persuaded or forced to accept. ${ }^{15}$

During a symposium organised in Ankara by the Turkish Naval Forces Command on October 14, 2006, Admiral Cem Gürdeniz, responsible for strategic planning at sea, strongly criticised the EU for adopting the "Seville map". As a follower of the Vatan Party, a group defined by its affection for Russia and its categorical opposition to the United States, Gürdeniz asserts that Washington intends to undermine Turkey's sovereignty in a coalition with other regional powers ${ }^{16}$, using Greece as a means towards that goal. Gürdeniz views Greece as a country that has a long history of allying itself with Western imperial powers. He went on to call on Turkey to defend a larger EEZ, which he named the "Blue Homeland". ${ }^{17}$ This proved to be the starting point for the formulation of a new doctrine for Turkey's territorial claims in the Aegean and the eastern Mediterranean seas.

Another high-ranking officer of the Turkish Navy, Rear Admiral Cihat Yaycl, published an article in 2009, building upon Gürdeniz's ideas and profoundly extending them to the point of a common maritime border between Turkey and Libya. ${ }^{18}$ In 2011, he further elaborated on this concept and on his interpretation of the international maritime legal framework as it is set out in the 1982 UNCLOS in a book he co-authored with a retired Colonel of the Turkish Armed Forces, Ali Karamahmut. ${ }^{19}$ There was a growing list of

${ }^{15}$ Cem Gürdeniz, "The Map of Seville and the plot to cut Turkey off from the Aegean and Mediterranean seas", United World, https://uwidata.com/13877-the-map-of-seville-andthe-plot-to-cut-turkey-off-from-the-aegean-and-mediterranean-seas/

${ }^{16}$ Ryan Gingeras, "Blue Homeland: the heated politics behind Turkey's new maritime strategy", War on the Rocks, June 2, 2020, https://warontherocks.com/2020/06/blue homeland-the-heated-politics-behind-turkeys-new-maritime-strategy/

${ }^{17}$ Aurélien Denizeau, "Mavi Vatan, the "Blue Homeland": The Origins, Influences and Limits of an Ambitious Doctrine for Turkey", Ifri, April 2021, p. 7.

${ }^{18}$ C. Yayci, "Doğu Akdeniz'de deniz yetki alanlarının sınırlandırılmasında Libya'nın rolü ve etkisi" [The role and influence of Libya in maritime security in the Mediterranean], Güvenlik Stratejileri [Journal of Security Studies], Vol. 7, No. 14, 2011, pp. 17-41.

${ }^{19}$ See, A. Kurumahmut and C. Yayci, Deniz subayları için temel deniz hukuku : Barış ve savaş dönemi [Fundamental maritime law for navy officers: in times of peace and war], Çanakkale: Deniz Kuvetleri Kültür, 2011. 
publications in support of the 'Blue Homeland' concept in the following years; to name but a few, Adm Soner Polat's book "Mavi Vatan için jeopolitik rota: Doğu Akdeniz, Kıbrıs ve Ege'deki kavgayı anlatan tespitler ve neriler", Adm Cem Gürdeniz' "Mavi Vatan yazıları" and "Anavatandan Mavi Vatan'a"20, etc.

The narrative of this doctrine serves to legitimise domestically the government's eastern Mediterranean policy, which has focused on the perceived threat that Turkey is being limited to Anatolia and its territorial waters. Therefore, it needs to maintain access to the Black, the Aegean, and the Mediterranean Seas by projecting a high profile. ${ }^{21}$ But at its core, this is a geopolitical concept that has been perceived and supported by the Turkish Navy, which claims through this a leading role in policy formation and implementation in the East Mediterranean Sea. The above is one of three ideas presented by the "Blue Homeland". The Libya case is an actual manifestation of Ankara's perception of expanded maritime boundaries. The second idea is the Turkish Navy's call to reimagine and reposition the country as a naval power. ${ }^{22}$ The augmentation and large-scale modernization of the Turkish Navy is a clear sign that it aims further than coastal deterrence. The third idea is about reimagining Turkey's position in the world and realigning the country away from the West and towards China and Russia. This is attributed to the nationalist and ultra-nationalist segments of the armed forces and the so-called Eurasianists. ${ }^{23}$ It also underlines the lack of trust in US impartiality in the eyes of the Turkish public and, from 2021, the anticipation that Turkey-US relations will deteriorate further under the Biden administration.

\footnotetext{
${ }^{20}$ S. Polat, Mavi Vatan için jeopolitik rota: Doğu Akdeniz, Kıbrıs ve Ege'deki kavgayı anlatan tespitler ve öneriler [The route to the Blue Homeland: Observations and recommendations from the conflict in the East Mediterranean Sea, Cyprus and the Aegean], Istanbul, Kaynak: 2019; C. Gürdeniz, Mavi Vatan yazıları [Writings on Blue Homeland], Kırmızı Kedi, 2018; C. Gürdeniz, Anavatandan Mavi Vatan’a [From Motherland to Blue Homeland], Kırmızı Kedi, 2021

${ }^{21} \mathrm{Al}$ Sharq Strategic Research, "The Eastern Mediterranean Crisis: Scenarios and Implications," Webinar Report, December 18, 2020, p. 8, https://research.sharqforum.org/ 2020/12/18/webinar-report-the-eastern-mediterranean-crisis-scenarios-and-implications/.

${ }^{22}$ Galip Dalay, p. 6.

${ }^{23}$ Cem Gürdeniz and Cihat Yaycı are leading figures in this.
} 


\section{THE “BLUE HOMELAND” AND THE TURKISH GOVERNMENT}

There is an understanding between the government and the ultranationalist and Eurasianist supporters of the "Blue Homeland", as far as the extended maritime borders and Turkey's role as a naval power are concerned. However, this does not extend to the third idea. The government seems to understand that there are limits to its relations with Russia. Economic ties and trade have been the driving forces behind them. However, in the arena of regional politics, their interests diverge and they are defined by a mixture of cooperation, competition, and conflict. This was exemplified in the cases of Syria, Libya, and Nagorno-Karabakh.

In Syria, Turkey's support for the opposition allowed Russia to dominate the Assad regime and reduce Iran's influence. The same pattern was used in the Libya conflict. Ankara's support for the Tripoli regime increased the reliance of Field Marshal Khalifa Haftar's forces on Russia's military backing in comparison to the other countries supporting his Tobruk-based Libya National Army (LNA). In the 2020 Armenia-Azerbaijan war, Turkey's increased support for the Azeri offensive led Yerevan to turn to Russia for help, thus consolidating Moscow as the dominant external power over Armenia. ${ }^{24}$ As it has been shown after the November 2015 Sukhoi incident, Russia is the dominant member in this asymmetric partnership. ${ }^{25}$ Moscow's measures against Turkey proved that Russia has significantly more ways to hurt Turkey, economically and politically, than the other way round. ${ }^{26}$ It was Ankara that sought Russia's cooperation after the Sukhoi incident, as a way to get out of a difficult regional and international diplomatic isolation branded "precious loneliness" by Ibrahim Kalin. ${ }^{27}$ Bilateral relations are bound to become more complicated in the coming years since the new administration in the White House aims to get the US once again involved in the East Mediterranean regional politics, in contrast with former President Trump's approach of

${ }^{24}$ Güney Yıldız, "Turkish-Russian Adversarial Collaboration in Syria, Libya, and NagornoKarabakh", SWP Comment, No. 22, March 2021, p. 1.

${ }^{25}$ On 24 November 2015, a Turkish F-16 jet shot down a Russian Sukhoi Su-24 near the Turkey-Syria border.

${ }^{26}$ Güney Yıldız, p. 3.

${ }^{27}$ By 2014, Turkey's "zero problems with neighbours" policy had collapsed, and the country was left with only a few neighbours with which it did not have problems. Major 
indifference to the level of contempt in certain cases of the developments in Syria and Libya. ${ }^{28}$

Relations with China are mainly economic-oriented. Trade volume has been growing steadily from 2000 onwards. Turkey is a member of China's Belt and Road Initiative ${ }^{29}$ and China is Turkey's biggest import partner. Turkey's lira crisis in 2018 and Erdoğan's commitment to avoid IMF intervention due to the negative political weight that it carries ${ }^{30}$, in addition to the "cold" relations with the USA and the EU as a product of Ankara's de-Europeanization and de-Westernization policies that followed the western actors' tepid reaction to the 2016 failed coup attempt ${ }^{31}$, led to statements by the Turkish President about seeking alternative power centres to balance the West. ${ }^{32}$ President Erdoğan claimed that Turkey might be forced to look for other friends and allies, citing apart from US reaction to the 2016 coup attempt, the nonextradition of Fethullah Gülen, US partnership with the PYD/YPG in Syria and the Andrew Brunson case. ${ }^{33}$ Regardless of the fact that warnings in the form

disagreements with Israel, Egypt, Syria, Iraq, and also with Saudi Arabia and Iran (albeit less severely), major disagreements with the US and the EU, together with anti-western outbursts from government members, have alienated many countries that used to admire the Turkish model of the early 2000s. See, David Gardner, "Turkey's foreign policy of precious loneliness", FT, 16 November 2015, https://www.ft.com/content/69662b36-775211e5-a95a-27d368e1ddf7

${ }^{28}$ Ian O. Lesser, "The Trump administration and Mediterranean", IEMED Mediterranean Yearbook 2017-Geopolitical turmoil and its effects in the Mediterranean region, pp 101-102. See also, Philip Stephens, "Home truths in the East Mediterranean", Financial Times, 3 September 2020, in https://www.ft.com/content/9ce8847f-6fe8-4208-8a1d-2d6b3425ad42

29 "Turkey's Multilateral Transportation Policy." Republic of Turkey Ministry of Foreign Affairs, http://www.mfa.gov.tr/turkey_s-multilateral-transportation-policy.en.mfa.

${ }^{30}$ Resorting to an IMF bailout would remind the Turkish public of the 2001 economic crisis and the political conditionality that Turkey had to consent to. The Turkish president, after Turkey paid-off the IMF debt, had promised to build a strong economy; a new IMF bail-out would undermine the AKP government's credibility.

${ }^{31}$ Ziya Öniş, "Turkey under the challenge of state capitalism: the political economy of the late AKP era", Southeast European and Black Sea studies, 2019, p. 10.

${ }^{32}$ Gözde Yılmaz, Nilgün Eliküçük Yıldırım, (2020) "Authoritarian diffusion or cooperation? Turkey's emerging engagement with Chine", Democratization, 27:7, p. 1208.

${ }^{33}$ R. T. Erdoğan, "Erdogan: How Turkey Sees the Crisis With the U.S.", New York Times, 10 August 2018, https://www.nytimes.com/2018/08/10/opinion/turkey-erdogan-trumpcrisis-sanctions.html 
of political statements about Turkey drifting away from the West are not new, there is a sense that after 2015, the AKP has been constructing a policy to support such a possibility. The 2018 currency crisis and eroded relations with the West presented an opportunity for Beijing to invest in Turkey's and China's overlapping interests. The Chinese Foreign Minister at the time, Wang Yi, stated that China was supporting Turkey's efforts for security, stability, and the economy. He added that China has remained ready to protect developing countries and the legitimate rights of rising economies. ${ }^{34} \mathrm{~A}$ threefold rise in China's Foreign Direct Investment in Turkey in 2017 could be a reflection of Beijing's increasing interest in capitalising on Turkey's lukewarm relations with the West, thus extending the economic collaboration to the political level. Such cooperation, however, does not come without cost; in the past, Turkey has been critical of Beijing's repression of the Uyghur minority ${ }^{35}$, but in recent years there have been no anti-China activities within Turkey's borders, although there were statements made after official high-profile visits, where mutual respect for safeguarding national security and stability was underlined as the main focus of the bilateral cooperation. ${ }^{36}$ The growing criticism of the Turkish government for adopting increasingly authoritarian policies could also interpret this convergence between Ankara and Beijing's authoritarian regime as an outcome of Turkey's distancing from the West.

All of the above would cast the question of Erdoğan's attitude towards the "Blue Homeland" narrative and the doctrine as a rhetorical one, considering the fact that Ankara's "'defence" policy seems to be using the narrative of the doctrine to legitimise its eastern Mediterranean policy. However, a careful look into Erdoğan's use of populism since the AKP's ascendance into power, proves

34 "China reiterates support for Turkey's economy", Hürriyet Daily News, 19 August 2018, https://www.hurriyetdailynews.com/china-reiterates-support-for-turkeys-economy135953

${ }^{35}$ The Uyghurs are a Turkic Muslim minority in the Xinjiang region that has been suffering from a decades-long crackdown by government officials. From 2014, Beijing has initiated a re-education effort - in reality a mass detention of Muslims policy - in so-called "vocational training centres". In 2017, there was a major expansion of the Xinjiang reeducation efforts. See, Lindsey Maizland, "China's repression of Uyghurs in Xinjiang", Council on Foreign Relations, 1 March 2021, https://www.cfr.org/backgrounder/chinasrepression-uyghurs-xinjiang

${ }^{36}$ Gözde Yılmaz, Nilgün Eliküçük Yıldırım, p. 1214. 
that the Turkish leader has been constantly shaping his foreign policy on different definitions of the "people". In his early years, he was committed to the Western Alliance and he modelled the European Christian Democrats, targeting EU membership, while the AKP rose to power as an anti-elite movement, targeting the decades-long Kemalist regime, by summoning the support of conservative pious Muslims, Islamists, a large segment of the Kurds and several liberals. In the AKP's second term, the "people" were redefined as a Muslim nation and foreign politics took a turn towards a proactive Islamist foreign policy and neo-Ottoman aspirations, while the failure to gain full EU-membership triggered a de-Europeanization process and rising anti-EU sentiments. Within this period that includes the 2011 Arab Uprisings, the 2013 Gezi Park protests, and the 2016 coup attempt, Erdoğan began to refer to "western imperialists" and "crusaders" after the 2013 fall of his close ally and ideological comrade, Mohammed Morsi, and the Muslim Brotherhood in Egypt, essentially using anti-Western rhetoric to consolidate his position within Turkey as "a founding father that will unite the people against their enemies" ${ }^{\prime 37}$ but also as a way to promote himself as a leading figure within the Muslim world.

In the post-2016 years, Erdoğan changed the definition of "people" once again, this time limiting it to the Turkish nation, excluding the Kurds. He adopts a new narrative where some global elites are targeting Turkey, aiming to divide and weaken the country. He turns to the far right political parties and commits to a close alliance with the MHP, adopts an anti-western discourse in foreign policy and reduces Turkey's relations with the EU and the US to transactionalism. ${ }^{38}$

\section{From the "Strategic depth" to the "Blue Homeland"}

Ahmet Davutoğlu's "Strategic Depth" doctrine, termed the "zero problems with neighbours" policy, is aimed at establishing good relations with all neighbouring states based on strategic cooperation, increased trade, and solidarity. ${ }^{39}$ According to Michaël Tanchum, this policy was just one

\footnotetext{
${ }^{37}$ Hakkı Taş, "The formulation and implementation of populist foreign policy: Turkey in the eastern Mediterranean", Mediterranean Politics, DOI: 10.1080/13629395.2020.1833160, p. 5.

${ }^{38}$ Hakkı Taş, p. 6.

${ }^{39}$ Ryan Gingeras, "Blue Homeland: the heated politics behind Turkey's new maritime strategy", War on the Rocks, June 2, 2020, https://warontherocks.com/2020/06/ bluehomeland-the-heated-politics-behind-turkeys-new-maritime-strategy/
} 
manifestation of a broader aim to create a "zone of peace and stability, starting from her neighbours" 40 , using "soft power" together with security for all, political dialogue, economic interdependence, and cultural harmony as its building blocks. ${ }^{41}$

The failure to realise the vision, due to the rapid changes in regional politics and Turkey's isolation in the international scene, as well as Davutoğlu's disagreements with Erdoğan, led to his resignation in May 2016, two months before the failed coup attempt. Within this period of time, Turkey took a sharp turn towards a strategic approach compatible with the Blue Homeland's spirit. This included a substantial increase in "hard power", an aggressive foreign policy, and a post-coup "witch hunt", initially against the supporters of Fethullah Gülen, gradually expanding to all of Erdoğan's political opponents.

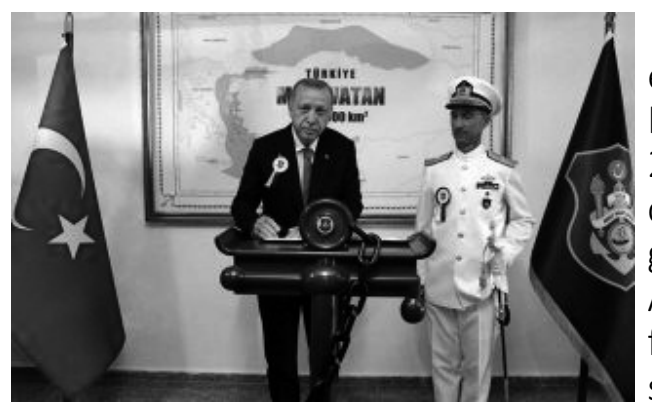

As it has been mentioned earlier in this paper, the "Blue Homeland" has been around since 2006, but 10 years later, it is still considered rather radical for the government and marginal for the AKP and the elites, as a result of the failed coup attempt that has seriously impaired civil-military relations. In the meantime, the father of the "Blue Homeland" narrative, Adm. Cem Gürdeniz, was arrested along with scores of other senior officers as a part of the broader "Sledgehammer" trials of 2011; he was convicted and sentenced to 18 years in prison, but he was released in 2015. ${ }^{42}$ After 2016, the "Blue Homeland" narrative started proliferating rapidly in Turkish politics, and by 2019, lieutenant colonel Engin Ağmış, Commander of the Gökçeada frigate, in his address to the Turkish president during a ceremony marking the anniversary of the establishment of the Turkish Republic, said: "I pledge that we are ready to protect every swath of our 462.000 square metre of Blue

\footnotetext{
${ }^{40}$ Michaël Tanchum "The Logic Beyond Lausanne: A Geopolitical Perspective on the Congruence between Turkey's New Hard Power and its Strategic Reorientation", Insight Turkey, 22(3), pp. 41-54, 2020. doi:10.25253/99.2020223.03

41 "Policy of Zero Problems with our Neighbours", Turkish Ministry of Foreign Affairs, https://www.mfa.gov.tr/policy-of-zero-problems-with-our-neighbors.en.mfa

${ }^{42}$ Ryan Gingeras, op.cit.
} 
Homeland with great determination and undertake every possible duty that may come" ${ }^{43} \mathrm{~A}$ picture of President Erdoğan in front of a Blue Homeland map, while he signed the visitors' book at the National Defence University in Istanbul that circulated widely in the media, added to the symbolism.

The other "Blue Homeland" theorist, former Chief of Staff of the Turkish Navy and the mastermind of the controversial Libya policy, RAdm Cihat Yaycl was demoted on May 15, 2020;44 Yaycl responded to his demotion by resigning only three days later. Apart from his involvement in the "Blue Homeland" and the Libya policy, which included the maritime boundaries and Exclusive Economic Zone (EEZ) MoU ${ }^{45}$ between Libya's GNA and Turkey, he has also been heavily involved in Erdoğan's fight against the Gülenist network in the aftermath of the 2016 failed coup attempt ${ }^{46}$ and has been praised by the Turkish president for his role in the Libya pact. This was the first time a high-ranking officer was demoted by presidential decree instead of at the biannual Supreme Military Council. Yaycı's demotion was interpreted as Erdoğan's effort to distance himself from the anti-Western front because of Turkey's need for the support of its western partners in order to control its increasing dependency on Russia and the economic hardships blamed on the COVID-19 pandemic. As Yaycı is a popular figure within Turkey's influential anti-Western and Eurasianist groups, his resignation caused a stir both in the pro-government and the opposition blocks, leading to criticism and calls for Erdoğan to reverse the admiral's demotion.

\footnotetext{
${ }^{43}$ Nikos Moudouros, "“"Blue Homeland" and Cyprus: The "Survival of the State" Coalition and Turkey's Changing Geopolitical Doctrine in the Eastern Mediterranean", Vestnik RUDN, 21:3, 2021, p. 460

${ }^{44}$ Aytunç Erkin, "İşte Tümamiral Cihat Yaycı'nın istifa dilekçesi!", Sözcü, https://www.sozcu. com.tr/2020/gundem/son-dakika-iste-tumamiral-cihat-yaycinin-istifa-dilekcesi-5822043/, 18 May 2020

${ }^{45}$ For the full text of the MoU, see: al-Marsad, https://almarsad.co/en/2019/12/05/exclusivefull-text-of-the-gna-turkey-agreement-claiming-to-be-an-mou-revealed/

${ }^{46}$ Metin Gurcan, "Top admiral's resignation rattles Turkey", Al-Monitor, https://www.almonitor.com/originals/2020/05/turkey-anti-western-admiral-yayci-resignation-rattleankara.html, 20 May 2020.
} 


\section{Foreign policy de-Europeanization and de-westernization}

The 2016 failed coup attempt was the locus of several changes in Turkey, related to internal and external politics. President Erdoğan had already engaged in anti-western rhetoric as early as 2013, blaming foreign elements for the Gezi Park protests and the popular uprising in Egypt that led to the fall of the Muslim Brotherhood from power - two developments that he thought were linked. However, as Turkey sought greater independence in pursuit of its foreign policy aims, it sharply increased its anti-western discourse and engaged in a series of crises with the West that led to its eventual isolation.

The arbitrary detention of western nationals in Turkey, which was used as a political bargaining chip and termed Turkey's "hostage diplomacy", strained its bilateral relations with several western countries, including Germany, the US, France, the Netherlands, and Greece, to name but a few. ${ }^{47}$ The purchase of the Russian-made S-400 anti-missile defence system rocked further Turkey-US relations and led to Turkey's expulsion from the F-35 Joint Strike Fighter consortium, a de-facto arms embargo, and in December 2020, the sanctioning of Turkey's SSB and key individuals under the 2017 C.A.A.T.S.A. ${ }^{48}$

The anti-Western crescendo was complemented by a de-Europeanization process that started after 2011 but was accelerated in 2014, which was a presidential election year in Turkey. The AKP's victory was followed by the

\footnotetext{
${ }^{47}$ More than 30 Western nationals have been jailed in Turkey following the coup attempt. See, Aykan Erdemir and Eric Edelman, "Erdoğan's hostage diplomacy - Western nationals in Turkish prisons", Foundation for Defence of Democracies, https://www.fdd.org/analysis /2018/05/31/erdogans-hostage-diplomacy-western-nationals-in-turkish-prisons/\#easyfootnote-bottom-3-35064, June 2018, p. 6.

48 Yörük Işık, "CAATSA sanctions are hurting Turkey's military readiness at a time when NATO can't afford it", Middle East Institute, https://www.mei.edu/publications/caatsa-sanctionsare-hurting-turkeys-military-readiness-time-when-nato-cant-afford-it, 6 May 2021. See also, Michael Pompeo, Secretary of State, December 14, 2020 Press statement, US Embassy in Athens, https://gr.usembassy.gov/the-united-states-sanctions-turkey-undercaatsa-231/; Stephen Reisinger, "US imposes CAATSA sanctions on Turkish SSB and related officers", Norton Rose Fulbright, https://www.nortonrosefulbright.com/en/knowledge/ publications/852a1100/us-imposes-caatsa-sanctions-on-turkish-ssb-and-related-officers, 17 December 2020
} 
construction of 'a new Turkey in its own image, in a fashion that was increasingly indifferent and inconsiderate of oppositional groups' ${ }^{\prime 4}$, which essentially introduced a socio-political process that aspired to an all-inclusive hegemonic narrative of the country. ${ }^{50}$ In foreign policy terms, the Arab uprisings worked as a catalyst for the "geographic imagination" of Turkey and the formulation of a new agenda. ${ }^{51}$ They actually provided the space for the AKP to promote Turkey as a "model" in the Arab world (and the Balkans) by instrumentalizing the narrative of official Turkish history, culture, and Sunni Islam..$^{52}$ As a result, Turkey's position towards the EU was reconfigured, putting more distance in an already strained relationship after the EU's attitude towards Turkey's membership bid and the AKP's efforts towards that goal in its early years in power. As Kemal Kirisçi argued, resentment towards the EU in Turkey was fuelled by "the EU's failure to respond promptly to the coup attempt and lend support to the government" and was further aggravated by the European Parliament's recommendations in November 2016 to suspend Turkey's membership negotiations..$^{53}$ Additionally, the European refugee crisis was another factor in the strain between Turkey and the EU. The EU accused Ankara of manipulating the refugee crisis by deliberately lacking border control along its Aegean coastline. The Turkish president, on the other hand, repeatedly threatened to open Turkey's borders and flood Europe with migrants to extract concessions. ${ }^{54}$

${ }^{49}$ Barış Alp Özden, İsmet Akça and Ahmet Bekmen, "Antinomies of authoritarian neoliberalism in Turkey: the Justice and Development Party in Turkey", C. B. Tansel (ed.) States of Discipline: Authoritarian Neoliberalism and the Contested Reproduction of Capitalist Order, London: Rowman \& Littlefield, p. 203.

${ }^{50}$ Nikos Christofis, "'Securitizing the Aegean': de-Europeanizing Greek-Turkish relations", Southeast European and Black Sea Studies, 22:1, 2022

${ }^{51}$ Nikos Christofis, Op. cit.

${ }^{52}$ Ahmet Erdi Öztürk, Religion, Identity and Power: Turkey and the Balkans in the twenty first century, Edinburgh: Edinburgh University Press, 2021.

${ }^{53}$ Kemal Kirişçi, Turkey and the West: fault lines in a troubled alliance. Washington: Brookings Institution Press, 2018, p. 172.

${ }^{54}$ Agence France-Presse in Ankara, "Turkish president threatens to send millions of Syrian refugees to EU”, The Guardian, https://www.theguardian.com/world/2016/feb/12/turkishpresident-threatens-to-send-millions-of-syrian-refugees-to-eu, 12 February 2016. 
As Turkey proceeded with its de-Europeanization process, it also abandoned its zealous ideological ambitions to promote the country as a "great power"55, as stated in Davutoğlu's "Strategic Depth" and pursued as the point of reference of the country's foreign policy during his involvement in AKP politics. ${ }^{56}$ Foreign policy switched to an "ad hoc" and transactional profile, defined by expediency, which led to high unpredictability and flipflopping in decisions. ${ }^{57}$

Essentially, Erdoğan's populism voiced a more antagonistic civilizational discourse, depicting Turkey as the heir to the Islamic and Ottoman civilizations, but also in a war of liberation from the West..$^{58}$ He portrayed the turmoil in EU-Turkey relations as a "clash of civilizations" by accusing EU politicians Kati Piri, Federica Mogherini, and Johannes Hahn of being enemies of Islam. ${ }^{59}$ During an interview with the pro-government Ülke TV, he stated, "They [K. Piri, F. Mogherini, and J. Hahn] are not honest, they are not sincere. We should not forget this: We are Muslims and they are enemies of Islam". ${ }^{60}$ MEP Kati Piri, in her response to Erdoğan's remarks, said that "by claiming that the West and the EU are enemies of Islam, he is trying to pit people against each other. He is laying the groundwork for massacres". ${ }^{61}$

${ }^{55}$ Katerina Dalacoura, "A new phase in Turkish foreign policy: expediency and AKP survival", MENARA Future Notes 4, Middle East and North Africa Regional Architecture, February 2017, p. 2.

${ }^{56}$ Ahmet Davutoğlu has been involved in AKP politics as a foreign policy advisor, as Foreign Minister and as Prime Minister, from 2003-2016.

${ }^{57}$ Hakkı Taş, p. 10.

${ }^{58}$ Alper Kaliber, Esra Kaliber, "From de-Europeanisation to anti-western populism: Turkish foreign policy in flux", The International Spectator, 54:4, p. 12, DOI:10.1080/03932729. 2019.1668640

59 This was a statement made by Erdoğan in his critique of a report that favoured the official freezing of negotiations with Turkey.

${ }^{60}$ SCF, Stockholm Centre for Freedom, Erdoğan calls some EU politicians 'Enemies of Islam', https://stockholmcf.org/erdogan-calls-some-eu-politiciansenemies-of-islam/, 25 March 2019.

61 "Erdoğan calls some EU politicians 'enemies of Islam'”, Turkish Minute, https://www. turkishminute.com/2019/03/23/erdogan-calls-some-eu-politicians-enemies-of-islam/, 23 March 2019. 


\section{THE "BLUE HOMELAND” DOCTRINE AND THE CRISIS IN THE EAST MEDITERRANEAN SEA}

The post-2016 years constitute a new period in Turkey's foreign policy. One where the "Blue Homeland" doctrine was increasingly reflected in its strategic posturing. The failure of Davutoğlu's "Strategic Depth" by 2012 left the field open for Cem Gürdeniz's strategic vision for the country's future.

The "Blue Homeland" has been gaining prominence both domestically and as a component of Turkey's foreign policy, which in the last five years has become increasingly aggressive and securitized, with an anti-Western and antiU.S. outlook as the central organising principle. ${ }^{62}$ It had established the defence of Turkey's maritime sovereignty as its first objective and set three goals: a) to ensure it possesses the capacity and capability to protect Turkey's interests in the surrounding seas. b) to strengthen Turkey's regional maritime boundary claims in order to gain access to new energy resources, increased influence, and economic growth, and c) to prevent the West from confining Turkey.

This last aim is referred to, colloquially, as the "second Treaty of Sevres", essentially drawing a parallel between the aim of the victors of World War I to dismantle the remnants of the Ottoman empire with the Treaty of Sevres and Turkey's perceived threat, where Greece, the US, the EU, and their allies in the east Mediterranean sea are aiming to sever the link between Turkey, its maritime jurisdictions, and the pseudo state of the self-proclaimed Turkish Republic of Northern Cyprus. ${ }^{63}$

As Ryan Gingeras argues, the shift in Turkey's foreign policy was not simply a matter of political discourse but a very drastic change in Turkey's geostrategic vision, and apparently, the idea is shared by many in Turkish politics and the military. ${ }^{64}$ Evidence of that is in abundance. The most striking

\footnotetext{
62 Jeff Jager, Andrew Norris, "The Mavi Vatan doctrine and Blue Homeland anthem: a look at Turkey's maritime worldview", Centre for International Maritime Security, https://cimsec. org/the-mavi-vatan-doctrine-and-blue-homeland-anthem-a-look-at-turkeys-maritimeworldview/, 27 September 2021.

${ }^{63}$ Füsun İkikardeş, "Mavi Savaş’ta Kıbrıs düğümünü Ankara-Şam teması çözer", Aydınlık, https://www.aydinlik.com.tr/mavi-savas-ta-kibris-dugumunu-ankara-sam-temasi-cozerturkiye-kasim-2019-1, 18 November 2019.

${ }^{64}$ Ryan Gingeras, op.cit.
} 
ones are the "Blue Homeland 2019" naval exercise and Turkey's Naval College journal, called "Mavi Vatan". ${ }^{5}$

Natural gas discoveries in the East Mediterranean Sea and Cyprus's EEZ delineation agreements sparked new trouble in the region, roughly in the last decade. Ankara has built five drilling and seismic research vessels and, in a direct reference to its neo-Ottoman narrative, it has symbolically named them after the influential Ottoman sultans and admirals who secured Ottoman naval dominance in the Mediterranean Sea during the $16^{\text {th }}$ century. ${ }^{66}$

The $2019 \mathrm{MoU}$ with Libya escalated the regional tensions immensely, in the middle of heightened gas exploration and drilling, overlapping NAVTEXs from Greece, Turkey, and Cyprus, naval standoffs in international waters, and the involvement of third-party states. The Med $7^{67}$ signed a joint declaration in June 2020, expressing their support for Greece and Cyprus against Turkey's belligerence in the region. ${ }^{68}$ The launching of the Eastern Mediterranean Gas Forum (EMGF) on September 22, 2020, which included seven members - Egypt, Israel, Greece, Cyprus, Jordan, Italy, and the Palestinian Authority - but excluded Turkey, ${ }^{69}$ was the peak of the latter's isolation in the East Mediterranean energy developments. As the "Blue Homeland" started dominating Turkey's geostrategic vision in the aftermath of the 2016 failed coup attempt, Ankara's foreign policy adopted an increasingly assertive and militarised character.

\section{CONCLUSION}

President Erdoğan, has been constantly reconfiguring his foreign policy, manoeuvring through domestic hardships and regional developments.

${ }^{65}$ Hakan Yapar, "From Strategic Depth to Blue Homeland and Beyond: Underst;anding Turkey's drift towards greater strategic autonomy", Instituto Espanol de Estudios Estratigicos, 40/2021, p. 9.

${ }^{66}$ These were the Fatih, the Yavuz, the Barbaros Hayrettin Paşa, the Oruç Reis and the Kemal Reis. See, Nikos Moudouros, p. 468.

${ }^{67}$ A group comprised of the foreign ministers of southern EU member states (Greece, Cyprus, Malta, Italy, France, Spain, and Portugal).

68 "Med7 calls on Turkey to respect law of the sea", Ekathimerini, https://www.ekathi merini.com/news/253441/med7-calls-on-turkey-to-respect-law-of-the-sea/, 4 June 2020.

69 Pınar İpek, V. Tibet Gür, "Turkey's Isolation from the Eastern Mediterranean Gas Forum: ideational mechanisms and material interests in Energy Politics", Turkish Studies, DOI: 10.1080/14683849.2021.1925884 
Although he has embraced Blue Homeland, his attitude suggests that he does not want Turkey's geopolitical posturing to be completely subjugated to the reign of the left-wing, ultranationalist circles that have conceptualised the doctrine. As such, he made some moves to downgrade their profile, as seen by the demotion of Cihat Yaycı. His replacement, Adm. Yankı Bağcıoğlu, is said to have told a French naval delegation that Turkey sticks to Blue Homeland along with its NATO commitments. This can be interpreted as Erdoğan's Turkey trying to avoid any decisive rupture with the West while asserting itself in the region at the same time.

There is criticism that Turkey's growing ties with Russia and China constitute a radical reorientation towards non-Western powers at the expense of Ankara's long-term allies. However, this shift should not be interpreted as a full-steam reorientation towards non-Western powers. Instead, Erdoğan's Turkey aims at achieving a higher status within the West by emphasizing its importance to the West through instrumentalizing tactical cooperation with non-Western powers, the likes of Russia and China. It is important to highlight that Turkey's relations with them are mostly transactional arrangements managed at a leader-to-leader level, as AydınDüzgit, Balta, and O' Donohue argue for Turkey's relations with Russia. ${ }^{70}$

Nevertheless, Turkey has been in dire straits for the last 5 years and has multiple challenges to address, including domestic, regional, and international issues. President Erdoğan is showing that he could be willing to manipulate a radical doctrine, such as the "Blue Homeland", to pursue his vision of Turkey, keeping it, however, under his complete control. It is unclear whether such a feat is possible; what is clear is that in a volatile area that has been under strain for several years, tampering with delicate balances that could destabilise an entire region is risky.

\section{BIBLIOGRAPHY}

Aydin-Düzgit S., Evren Balta and Andrew O' Donohue, "Turkey, Russia, and the West: Reassessing persistent volatility, asymmetric interdependence, and the Syria conflict", Istanbul Policy Centre, April 2020.

\footnotetext{
70 Senem Aydin-Düzgit, Evren Balta, Andrew O' Donohue, "Turkey, Russia, and the West: Reassessing persistent volatility, asymmetric interdependence, and the Syria conflict", Istanbul Policy Centre, April 2020, pp. 9-10.
} 
Christofis N., "Securitizing the Aegean': de-Europeanizing Greek-Turkish relations", Southeast European and Black Sea Studies, 22:1, 2022

Dalacoura K., "A new phase in Turkish foreign policy: expediency and AKP survival", MENARA Future Notes 4, Middle East and North Africa Regional Architecture, February 2017.

Dalay G., "Turkey, Europe, and the Eastern Mediterranean: Charting a Way Out of the Current Deadlock", Brookings Doha Center Policy Briefing January 2021

Denizeau Au., "Mavi Vatan, the "Blue Homeland": The Origins, Influences and Limits of an Ambitious Doctrine for Turkey", Ifri, April 2021

Erdemir A. and Eric Edelman, "Erdoğan's hostage diplomacy - Western nationals in Turkish prisons", Foundation for Defence of Democracies, https://www.fdd.org/analysis/2018/05/31/erdogans-hostage-diplomacywestern-nationals-in-turkish-prisons/\#easy-footnote-bottom-3-35064, June 2018

Erdoğan R.T., "Erdogan: How Turkey Sees the Crisis With the U.S.", New York Times, 10 August 2018, https://www.nytimes.com/2018/08/10/opinion /turkey-erdogan-trump-crisis-sanctions.html

Erkin A., "Iş̧te Tümamiral Cihat Yaycı'nın istifa dilekçesi!", Sözcü, https://www.sozcu.com.tr/2020/gundem/son-dakika-iste-tumamiralcihat-yaycinin-istifa-dilekcesi-5822043/, 18 May 2020

Gardner D., "Turkey's foreign policy of precious loneliness", FT, 16 November 2015, https://www.ft.com/content/69662b36-7752-11e5-a95a-27d368 e1ddf7

Gingeras R., "Blue Homeland: the heated politics behind Turkey's new maritime strategy", War on the Rocks, June 2, 2020, https://waron therocks.com/2020/06/bluehomeland-the-heated-politics-behindturkeys-new-maritime-strategy/

Gurcan M., "Top admiral's resignation rattles Turkey", Al-Monitor, https://www.al-monitor.com/originals/2020/05/turkey-anti-westernadmiral-yayci-resignation-rattle-ankara.html, 20 May 2020.

Gürdeniz C., “Amiral Cem Aziz Çakmak'ı 'Mavi Vatan’ın sonsuzluğuna uğurlarken" [Our farewell to Adm Cem Aziz Çakmak who has departed to the eternal Blue Homeland], Aydınlık, July 4, 2015 
Gürdeniz C., "The Map of Seville and the plot to cut Turkey off from the Aegean and Mediterranean seas", United World, https://uwidata.com/ 13877-the-map-of-seville-and-the-plot-to-cut-turkey-off-from-the-aegean -and-mediterranean-seas/

Gürdeniz C., Anavatandan Mavi Vatan'a [From Motherland to Blue Homeland], Kırmızı Kedi, 2021

Gürdeniz C., Mavi Vatan yazıları [Writings on Blue Homeland], Kırmızı Kedi, 2018

Gürel A., Fiona Mullen, Harry Tzimitras, "The Cyprus Hydrocarbons Issue: Context, Positions and Future Scenarios", PCC Report 1, Peace Research Institute Oslo, 2013.

İkikardeş F., "Mavi Savaş’ta Kıbrıs düğümünü Ankara-Şam teması çözer", Aydınlık, https://www.aydinlik.com.tr/mavi-savas-ta-kibris-dugumunuankara-sam-temasi-cozer-turkiye-kasim-2019-1, 18 November 2019.

Ipek P. and V. Tibet Gür, "Turkey's Isolation from the Eastern Mediterranean Gas Forum: ideational mechanisms and material interests in Energy Politics", Turkish Studies, DOI: 10.1080/14683849.2021.1925884

Işı Y., "CAATSA sanctions are hurting Turkey's military readiness at a time when NATO can't afford it", Middle East Institute, https://www.mei.edu/ publications/caatsa-sanctions-are-hurting-turkeys-military-readinesstime-when-nato-cant-afford-it, 6 May 2021.

Jager J. and Andrew Norris, "The Mavi Vatan doctrine and Blue Homeland anthem: a look at Turkey's maritime worldview", Centre for International Maritime Security, https://cimsec.org/the-mavi-vatan-doctrine-and-bluehomeland-anthem-a-look-at-turkeys-maritime-worldview/, 27 September 2021.

Kaliber A., Esra Kaliber, "From de-Europeanisation to anti-western populism: Turkish foreign policy in flux", The International Spectator, 54:4, DOI:10.1080/03932729.2019.1668640

Kirişçi K., Turkey and the West: fault lines in a troubled alliance. Washington: Brookings Institution Press, 2018.

Kurumahmut A. and C. Yayci, Deniz subayları için temel deniz hukuku : Barış ve savaş dönemi [Fundamental maritime law for navy officers: in times of peace and war], Çanakkale: Deniz Kuvetleri Kültür, 2011. 
Lesser I. O., "The Trump administration and Mediterranean", IEMED Mediterranean Yearbook 2017- Geopolitical turmoil and its effects in the Mediterranean region.

Maizland L., "China's repression of Uyghurs in Xinjiang", Council on Foreign Relations, 1 March 2021, https://www.cfr.org/backgrounder/chinasrepression-uyghurs-xinjiang

Mateos J. R. and J. L. Suárez De Vivero, "Maritime Europe and EU Enlargement: A Geopolitical Perspective", Marine Policy, Vol. 30, No. 2, March 2006

Moudouros N., "'Blue Homeland" and Cyprus: The "Survival of the State" Coalitionand Turkey's Changing Geopolitical Doctrine in the Eastern Mediterranean", Vestnik RUDN, 21:3, 2021.

Öniş Z., "Turkey under the challenge of state capitalism: the political economy of the late AKP era", Southeast European and Black Sea studies, 2019

Örnek Ö., "Tümamiral Mustafa Özbey'den çağrı: Mavi Vatan okul müfredatına girsin" [An appeal by RAdm Mustafa Özbey: that Blue Homeland is included in school programs], Aydınlık, April 21, 2020

Örnek Ö., Milgem'in öyküsü [The Milgem history program], Istanbul: Kırmızı Kedi, 2016

Özden B.A., İsmet Akça and Ahmet Bekmen, "Antinomies of authoritarian neoliberalism in Turkey: the Justice and Development Party in Turkey", C. B. Tansel (ed.) States of Discipline: Authoritarian Neoliberalism and the Contested Reproduction of Capitalist Order, London: Rowman \& Littlefield.

Öztürk A.E., Religion, Identity and Power: Turkey and the Balkans in the twenty first century, Edinburgh: Edinburgh University Press, 2021.

Polat S., Mavi Vatan için jeopolitik rota: Doğu Akdeniz, Kıbrıs ve Ege'deki kavgayı anlatan tespitler ve öneriler [A geopolitical course to Blue Homeland: findings and proposals on the conflict in the Eastern Mediterranean, Cyprus and the Aegean], Istanbul: Kaynak, 2019

Pompeo M., Secretary of State, December 14, 2020 Press statement, US Embassy in Athens, https://gr.usembassy.gov/the-united-states-sanctionsturkey-under-caatsa-231/

Reisinger St., "US imposes CAATSA sanctions on Turkish SSB and related officers", Norton Rose Fulbright, https://www.nortonrosefulbright.com/ 
en/knowledge/publications/852a1100/us-imposes-caatsa-sanctions-onturkish-ssb-and-related-officers, 17 December 2020

SCF, Stockholm Centre for Freedom, Erdoğan calls some EU politicians 'Enemies of Islam', https://stockholmcf.org/erdogan-calls-some-eupoliticiansenemies-of-islam/, 25 March 2019.

Stephens P., "Home truths in the East Mediterranean", Financial Times, 3 September 2020, in https://www.ft.com/content/9ce8847f-6fe8-4208$8 a 1 d-2 d 6 b 3425 a d 42$

Tanchum M., "The Logic Beyond Lausanne: A Geopolitical Perspective on the Congruence between Turkey's New Hard Power and its Strategic Reorientation", Insight Turkey, 22(3), pp. 41-54, 2020. DOI: 10.25253/ 99.2020223.03

Taş H., "The formulation and implementation of populist foreign policy: Turkey in the eastern Mediterranean", Mediterranean Politics, DOI: 10.1080/ 13629395.2020.1833160

Yapar H., "From Strategic Depth to Blue Homeland and Beyond: Underst;anding Turkey's drift towards greater strategic autonomy", Instituto Espanol de Estudios Estratigicos, 40/2021.

Yaşar, N. T., "Syria and Libya's contributions to the evolution of the Turkish "Forward Defence" doctrine", Syria Transition Challenges Project: Research Project Report 7, Geneva Centre for Security Policy: 2021.

Yayci C., "Doğu Akdeniz'de deniz yetki alanlarının sınırlandırılmasında Libya'nın rolü ve etkisi" [The role and influence of Libya in maritime security in the Mediterranean], Güvenlik Stratejileri [Journal of Security Studies], Vol. 7, No. 14, 2011.

Yıldız G., "Turkish-Russian Adversarial Collaboration in Syria, Libya, and Nagorno-Karabakh", SWP Comment, No. 22, March 2021.

Yılmaz G., Nilgün Eliküçük Yıldırım, (2020) "Authoritarian diffusion or cooperation? Turkey's emerging engagement with Chine", Democratization, 27:7.

Agence France-Presse in Ankara, "Turkish president threatens to send millions of Syrian refugees to EU", The Guardian, https://www.theguardian.com/ world/2016/feb/12/turkish-president-threatens-to-send-millions-ofsyrian-refugees-to-eu, 12 February 2016. 
Al Sharq Strategic Research, "The Eastern Mediterranean Crisis: Scenarios and Implications," Webinar Report, 18 December 2020, https://research. sharqforum.org/2020/12/18/webinar-report-the-eastern-mediterraneancrisis-scenarios-and-implications/

Al-Marsad, https://almarsad.co/en/2019/12/05/exclusive-full-text-of-the-gnaturkey-agreement-claiming-to-be-an-mou-revealed/, 5 December 2012.

"China reiterates support for Turkey's economy", Hürriyet Daily News, https://www.hurriyetdailynews.com/china-reiterates-support-for-turkeyseconomy-135953, 19 August 2018

"Erdoğan calls some EU politicians 'enemies of Islam'”, Turkish Minute, https://www.turkishminute.com/2019/03/23/erdogan-calls-some-eupoliticians-enemies-of-islam/, 23 March 2019.

"Med7 calls on Turkey to respect law of the sea", Ekathimerini, https:// www.ekathimerini.com/news/253441/med7-calls-on-turkey-to-respectlaw-of-the-sea/, 4 June 2020.

"Policy of Zero Problems with our Neighbours", Turkish Ministry of Foreign Affairs, https://www.mfa.gov.tr/policy-of-zero-problems-with-our-neighbors.en.mfa

"Turkey's Multilateral Transportation Policy." Turkish Ministry of Foreign Affairs,http://www.mfa.gov.tr/turkey_s-multilateral-transportationpolicy.en.mfa 